\title{
FUNDAMENTAL RIGHTS AND THE NIGERIAN DRAFT CONSTITUTION
}

\author{
A.S. Fadlalla
}

The thinking on human rights in the world today is dominated largely by the western liberal and socialist traditions. This is perhaps a reflection of the hegemony of Europeans and the dominance of their culture in the world since the industrial revolution, and not an indication that human rights were unknown to non-western ideologies such as Islam ${ }^{1}$ or traditional African beliefs ${ }^{2}$.

The liberal and socialist traditions start from different ideological assumptions about the nature of man and human society. Basing itself on the writings of Locke $^{3}$, the natural rights of man to life, liberty and property - summed perhaps all in the right to property ${ }^{4}$ - western liberalism developed the economic doctrine of Laissez-faire, and saw the protection of human rights mainly in the non-interference of governments with these natural rights ${ }^{5}$. The socialists, relying mainly on Marx, dismissed natural rights as the rights of „egoistic man, of man separated from other men and from the community" 6 , and denied that an individual could have any rights separate from the group to which he belongs? They saw in the right to property a right of one man to exploit others ${ }^{8}$, and thus insisted on the socialisation of the means of production. Only in this way they felt can man be prevented from exploitation and thus allowed maximum opportunity for self realisation ${ }^{9}$.

However, there is now a considerable interaction between these two traditions, reflecting itself both at the international and national levels. The International Declaration of Human Rights now embodies both civil and political rights of the liberal tradition, and social and economic rights in the socialist fashion ${ }^{10}$. The International Commission of Jurists, in an attempt to meet the needs of developing countries, modified its original formulation of the rule of law and recognised that there are two aspects to this rule - the restraining aspect that calls for the non-interference of governments with the political and civil rights of individuals, and the dynamic aspect that allows governments to interfere positively in the economic and social sphere to protect the needy and the poor ${ }^{11}$. On the national level we have the welfare state, where it was felt that the greater economic and social good of the greater number requires the abandonment of the "hands off" approach of Laissez-faire and the adoption of public measures directly aimed

1 Maududi, A. Islamic Law and Constitution, 4th ed. Lahore, 1969 pp. 235-241.

2 Allott, A, "The African Conception of the Rule of Law" in Development for what? (Hallowell ed.), 1964 p. 75 at $98-100$.

3 Two Treatise on Government (Peter Lasset's edition), Cambridge, 1960, Second Treatise, S. 6.

4 Tawney, R. H., The Acquisitive Society, London, 1926 p. 14.

5 Raphael, D. D., "The Liberal Western Tradition of Human Rights ${ }^{\alpha}$, International Social Science Journal Vol. XVIII No. 1, 1966 p: 23

6 Marx, K. “On the Jewish Question” in Karl Marx: Early Writings (T. B. Bottomre Trans. \& ed.), London, 1963 p. 24.

7 Williams, R., The Long Revolution, London, 1961 pp. 90-91.

8 Marx, ibid p. 25.

9 Hirszowicz, Maria, "The Marxist Approach" in International Social Science Journal op. cit. p. 11.

$10 \mathrm{On}$ this issue contrast the views of Cranston, M., Human Rights Today, London, 1962 pp. 38-42, with those of Raphael op. cit. pp. 25-27.

11 The Rule of Law in a Free Society, Geneva, 1959 p. 3. 
at general economic betterment ${ }^{12}$. And in the socialist tradition, the interaction manifested itself in constitutional guarantees of civil rights such as the right to freedom of expression, though the cynic may contend that these were merely nominal13.

This introduction is perhaps called for as a background to the current debates on fundamental rights in Nigeria, for it is the political philosophy that a state adopts which is likely to determine which rights find prominence in its Constitution.

Constitutional guarantees of freedom were first adopted in Nigeria in 1959. Commentators ${ }^{14}$ agree that this was due to the recommendation of the Willink Commission on Minorities. The Commission while not accepting the demands made by certain parties that more regions should be created in Nigeria, and while not itself really believing in the efficacy of fundamental guarantees of freedom nor did it find any widespread support for them - nevertheless recommended the inclusion of fundamental rights in the Constitution because their presence defines beliefs widespread among democratic countries ${ }^{15}$. And while admitting that a government determined to abandon democratic courses will always find ways of violating them, the commission hoped that their inclusion would be of great value in preventing a steady deterioration in standards of freedom and the unobtrusive encroachment of a government on individual rights ${ }^{16}$.

\section{Criticism of Fundamental Rights Under the 1963 Constitution}

The approach which the Constitution Drafting Committee adopted was to examine the existing guarantees under the 1963 Constitution and to make recommendations for their improvements. In as much as there has not been a fundamental change in the ideological orientation of the state, the procedure adopted seems justified, as on the whole the 1963 Provisions are as extensive as any list of fundamental rights in a liberal democracy can be. Indeed one commentator at least has long declared that he was „in favour of retaining the fundamental rights provisions in the present form, for purposes of any future Constitution". However, as we know, many criticisms have expressed about these provisions.

\section{(i) Liberal Rights}

The criticism here made was that the rights guaranteed were all of the liberal type dealing only with civil and political rights. This, to my mind, was a reflection of the political orientation at the time. The politicians who were agitating for such entrenchment hoped that they would be able to maximise their political freedom

\footnotetext{
12 Jones, H. W., “The Rule of Law and the Welfare State", Essays on Jurisprudence from the Columbia Law Review. N. Y. 1963, p. 400 - But see Hayek, F. A. 'The Road to Serfodon, London, 1944. Hayek, however, modified his original uncompromising stand on the welfare state. See The Constitution of Liberty, London, 1960.

13 Kiralfy, A. K. R. "The Rule of Law in Communist Europe" I \& C. L. Q., 1959, Vol. 8 p. 465.

14 e. g. Ezejiofer, G., Protection of Human Rights, under the Law London, 1964 pp. 178-183 op at 183., de Smith, S. A., The New Commonwealth and its Constitutions, London, 1964 pp. 177-179.

15 Cmnd 505 (1958), 97 quoted by de Smith op. cit. p. 179.

16 Park, A. "The Independence Constitution of Nigeria in Retrospect." Post-Independence Constitutional Changes (Memo.), Collected Seminar Papers, University of London Institute of Commonwealth Studies, No. 5,1968 p. 58 at 61 .
} 
of expression and association, and thus hoped to gain more supporters. ${ }^{17}$ No doubt many of them hoped to create a liberal parliamentary democracy in Nigeria on the basis of the Westminster Model with Britain as the ideal.

Today, some 18 years later, the basic ideology may have been modified, but not changed. This may explain why still no social or economic rights are included. A further explanation could be that since "most of the debate on the Draft of the chapter on Fundamental Rights took place in the Legal Drafting Sub-committee"18, the traditional lawyer's insistence that such rights are by their very nature not justiciable prevailed.

"To fail to guarantee the right to work or to enjoy social security may be bad politics, but it is not thought to be bad law; for a Constitution is primarily a legal document; rights ought not to be "guaranteed" in it unless they can be judicially enforced"19. The reason being, according to the Constitution Drafting Committee that "these rights only come into existence after the government has provided facilities for them" 20 .

The solution adopted, following the example of India, Ireland and other countries, was to include these social and economic rights in the section on the fundamental objectives and directive principles of the state; perhaps recognising also that a constitution could be a political as well as a legal document; a programme of action as much as it is a list of legal limitations .But like all compromises, it has criticsm going both ways ${ }^{21}$, and, as we shall point later, it may not be without its future problems.

\section{(ii) A mere declaration of existing rights}

The point is often made that the provisions of the constitution dealing with fundamental rights appear, for the most part, to be largely merely declaratory of existing law ${ }^{22}$. This need not be a serious criticism. First - since Nigeria enjoys a common law system, certain rights are embodied in that system before the adoption of the bill of rights, even though not in the same degree as in the United Kingdom. And secondly, though the rights may be merely declaratory to begin with, they acquire a fundamental status once incorporated and entrenched in the Constitution, and the whole issue will turn on the way the judiciary interpret such sections.

\footnotetext{
17 Ibid.

18 Report of the Constitution Drafting Committee, Lagos, 1976, Vol. 1 p. XV.

19 De Smith, op. cit. p. 185.

$20 \mathrm{CDC}$ Report, Vol. 1 p. XV. This ideological intention is spelted out more clearly in the next page. "Most of the fundamental rights are in a sense natural right; vested in every individual and to which he is entitled without any obligation or duty on the part of the government to provide facilities for their enjoyment. . To insist that the right to freedom of expression is the same kind of "right" to the "right" to free medical facilities and can be treated alike in a Constitutional document is, the majority of us feel, basically unsound." Report p. XVI. Compare this with the views of Cranston, and Raphael's reply. See footnote 10 above.

21 Dr. Abiola Ojo expressed the opinion that they must be expunged. See Sunday Times, Oct. 24,1976 p. 12 On the other hand, two members of the CDC Drs. Osoba and Usman hold the view that economic and social rights must be made justiciable.

22 Holland, D. C. "Human Rights in Nigeria" (1962) C.L.P. p. 145, at 148.
} 
Perhaps a more serious criticism is the one that points to the far reaching exceptions made to the fundamental rights provisions, so much so that they have been described as "a Bill of Exceptions, not a Bill of Rights"23. This would, to a great extent, apply equally to the proposals under the Draft Constitution.

Now there are two ways in which justiciable guarantees of rights could be entrenched in the Constitution. Either in a more generally worded guarantee e. g. "Speech shall be free"; or to spell out clearly the rights and the exceptions that justify their restriction. The first example is that adopted by the American Constitution, and in such a system a wide scope is left to the judiciary to determine the limits of those rights. Would it then be advisable to adopt such a system in Nigeria? To my mind the answer is No. Not because the judiciary could not be entrusted with this task, but because of the heavy burden it may impose on the judges and, considering the nature of politics in the country, it may be unfair to trust such a heavy responsibility on them ${ }^{23}$. It is interesting to note here that during the current debate on the Constitution, nobody seems to have questioned the issue of judicial review or the powers given to the judiciary in relation to the legislature. Everybody seems to assume that it is a good thing. This is not necessarily so. Judicial review is „a double-edged sword" and, if the assumption behind it is that legislatures misbehave occasionally, "the difficulty is that the judges will also misbehave occasionally, and will prevent the legislators from acting in the public interest"25. That judicial review is now taken for granted in Nigeria is due, to my mind, to the way the guarantees of rights have been framed as well as the cautious nature in which the courts have carried out their task.

If you agree with me that the rights cannot be framed in absolute terms, we may now examine the nature of the exceptions. For this purpose, the rights guaranteed fall into two types: First, those subject to certain enumerated restrictions such as the right to life, right not to be subjected to inhuman treatment, slavery or forced labour and personal liberty ${ }^{26}$. The exceptions to some of these rights - such as the right to personal liberty - are quite extensive. Nevertheless, this does not render them completely ineffective. By entrenching such rights in the Constitution, any further limitation to it had to be introduced by way of a constitutional amendment ${ }^{27}$; any action short of that would be struck out by the courts as unconstitutional. However, these rights could be restricted to the extent that is reasonably necessary during an emergency. The objection is not so much to this, as to the fact that an emergency under the 1963 Constitution could be easily declared by Parliament ${ }^{29}$, and the question was presumably not within the competence of the courts ${ }^{30}$.

\footnotetext{
23 Nwabueze, B. O. Constitutional Law of the Nigerian Republic, London, 1964 p. 393.

24 See de Smith, S. A., Fundamental Rights in Commonwealth Constitutions (1962) Journal of the Parliaments of the Commonwealth Vol. 43, p. 10 at 11

25 Schmeiser, D. A. Civil Liberties in Canada, London (OUP) 1964 p. 29. Schmeiser deals admirably with the pros and cons of judicial review pp. 26-36. See more recently. Dahrendorf, R., "A Confusion of Powers: Politics and the Rule of Law", (1977) M.L.R. Vol. 40 No. 1 p. 1, Dahrendorf speaks of "judicial despotism".

26 See Section $18-21$ of 1963 Constitution.

27 Perhaps this is why preventive detention never existed in the first Republic. See Park op. cit p. 61.

28 Doherty v. Balewa (1961) N.N.L.R. 604.

29 S. 70 (3) of 1963 Constitution.

30 Williams v. Majekodumni (1962) All N.L.R. 413
} 
The second group of rights such as freedom of private family life, of conscience, expression etc. are subject to restrictions that are "reasonably justifiable in a democratic society" in the interest of defence, public safety, public order, public morality or public health ${ }^{31}$. Here the legality or otherwise of the restriction will depend on the interpretation given to the words "reasonably justifiable in a democratic society" an expression which eludes any clear cut definition ${ }^{32}$, and its utility as a measuring yard is very doubtful. The courts in Nigeria maintained that they are the arbiters of what amount to this ${ }^{33}$, but no satisfactory written interpretation seems to have evolved. In Cheranci v. Cheranci ${ }^{34}$, Mr. Justice Bate suggested that for a restriction to be reasonable justifiable, it must meet the twin test of being both necessary and not excessive or out of proportion ${ }^{35}$. This to my mind, was a fairly good working tool, had it not been for the fact that Bate J. threw the burden of proof on the person who alleges that his right was infringed. In Williams v. Majokodumni, Bairamian F. J. said that the words "reasonably justifiable in a democratic society" must be read in the context of the constitution, and more particularly in the context of Chapter III in which they occur; and therefore the fundamental rights can only be invaded, if at all, to "the extent that is essential for the sake of some recognised public interest; and no further" 36 . But the least satisfactory cases are, of course, D.D.P. v. Chike $\mathrm{Obi}^{37}$ where the abnoxions colonial legislative relating to sedition was found to be still constitutional, and R. v. Amalgamated Press of Nigeria ${ }^{38}$ where we are told that the constitution guarantees nothing but ordered freedom; both unnecessarily limiting the armbit of the section protecting freedom of expression.

It is rather surprising, therefore, that the Constitution Drafting Committee decided to keep this operative clause in its original form ${ }^{39}$.

I share the view recently expressed by Prof. Ezejiofor ${ }^{40}$ that the word "necessary" should be substituted for "reasonably justifiable", because something could be reasonably justifiable without being necessary.

\section{(iv) Cautious Judicial Attitude}

The way in which the judiciary interpreted the fundamental rights provisions so far has been subjected to many critisms. First by adopting a presumption of constitutionality that favoured the legislation that is challenged ${ }^{41}$, and secondly, at times adopting the "not-doing" technique ${ }^{42}$, by treating the matter before

\footnotetext{
31 See for example s. 25 of the 1963 Constitution.

32 Democracy is one of those echo words that may mean all sort of things to different people and as a "democratic society" is, to me no less ambigious. And I must confess that I have not read the case of Patal v. A-G. for Zambia HP/Const./Re. J1/1968 in which, according to Dr. Aihe, the definition of the phrase “democratic society" is given - See Aihe, D. O. "An Evaluation of the Role of the Judiciary in the working of the Constitution since 1960", (1971) The Quarterly Journal of Administration, Vol. V No. 4 p. 439 at 443 n. 2.

33 D.D.P. v. Chike Obi (1961) 1 All N.L.R. 180.

34 (1960) N.L.R. 24.

35 Ibid, at p. 29.

36 See note 30 above. In this case the restriction order made against Chief Williams was found to be not reasonably justifiable.

37 Note 33 above.

38 (1961) 1 All N.L.R. 199.

39 Draft Constitution s. 38.

40 Exejiofor, G. "Comments on Fundamental Rights, Provisions of the Draft Constitution", a paper read at the Nigerian Bar Association. Workshop on the Draft Constitution. Lagos, 25-27 Nov., 1976.

41 Arzika v. Governor, Northern Region (1961) 1 All N.L.R. 379 Cheranci v. Cheranci above, note 34.

42 The expression was used by Bickel, The Least Dangerous Branch New York, in relation to the supreme court in America, quoted by Proehl, P. O. Fundamental Rights under the Nigerian Constitution
} 
them as if the fundamental rights provisions do not exist ${ }^{43}$, and thirdly by taking an unnecessary rigid stand on the issue of locus standi ${ }^{44}$. There is certainly a lot that recommends judicial restraint, certainly at the formative stages when the provisions are new, and the politicians may be suspicious of the judiciary. But a too cautious attitude may be just as harmful, as "precedents set in the formative years of the life of the constitution tend to take root" 45 .

\section{The Draft Recommendations}

One hopes that the course taken in this paper so far is justified by the fact that the scheme for the new recommendations generally follows the pattern of the 1963 Constitution, and all the points raised so far will equally apply to the new guarantees with the exception which we have already noted of the inclusion of a non-justiciable list of directive principals on the social and economic policy of the state. It remains to consider some of the specific improvements effected in the draft, certain issues of controversy and possible problematic areas in the future.

\section{(a) Marked Improvements}

The Draft Provisions - provided you do not question the ideology behind them - reflect marked improvements both in form and in substance. To begin with, the previous negative form of stating the rights, had been abandoned in favour of a more positive formulation. For example, whereas in the past, it was stated that "No person shall be deprived intentionally of his life"46, the Draft asserts that "Every person has a right to life" ${ }^{47}$, thus emphasising the right first before enumerating the exceptions when such a right could be lawfully taken away. The negative form, however, appears when detailed exceptions have to be made such in the section dealing with fair hearing. However, the drafting of section 38 (the section governing the restriction of certain fundamental rights) could be improved by putting the emphasis on those rights rather than on the exceptions to them. Instead of stating that nothing in these sections shall invalidate any law, in could have been stated in the form that the rights guaranteed under those sections can only be derogated from by a law which is reasonably justifiable etc. ${ }^{49}$. This will at least have a psychological effect on the minds of those who have to determine the legal limits of possible intervention with such rights.

Other amendments are as much a matter of form as of substance. Section 19 and 20 of the 1963 Constitution on inhuman treatment, slavery and forced labour are now

1960-1965, Occasional paper No. 5, African Studies Centre, Univ. of California, Los Angeles, 1970 , pp. 20-24. Bickel calls these techniques the possive virtues, but Professor Prochl adds that to others they may be the passive vices.

43 Merchants Bank Ltd. v. Federal Ministry of Finance (1961) All N.L.R. 598. See the comment on this case Prof. Seidman, ${ }^{\alpha}$ Constitutional Standards of Judicial Review and Administrative Action in Nigeria" - (1966) N.L.T. J. Vol. 1 No. 2 at 242.

44 Olawoyin v. A. G., Eorthern Region (1961) All N.L.R. 269

45 de Smith, The New Commonwealth \& its Constitutions op. cit. p. 190

461963 Constitution s. 18 (1).

47 Draft Constitution s. 26 (1).

48 Draft Constitution s. 29 (8), 9 (a).

49 See Ojo, A., "Constitutional Law and Administrative Law: The need for Reform". A paper read at the Annual Conference of the Nigerian Association of Law Teachers held at the University of Ife, April 1974 pp. $12-13$. 
brought together under the new section on the right to dignity of the human person ${ }^{50}$. Not only that, but the exceptions that previously validated certain customary punishment as have existed on November 1959 (e.g. Hadi Lashing) have now been deleted ${ }^{51}$. Two specific rights will now be considered. Personal Liberty 52: A person detained shall now be informed in writing within 24 hours and in language that he understands of the facts and grounds for his arrest and detention. Considering that a person unlawfully detained is entitled to compensation - and also to a public apology, a new addition - the writing requirement could prove useful in some future proceedings. Whether it is going to work effectively in practice is another matter. The section also tries to see to it that those arrested have their cases quickly dealt with setting maximum time limits within which they must be tried on or else released either unconditionally or on such conditions as are reasonably necessary to ensure their appearance before a court at a later date ${ }^{53}$. One hopes that this subsection would be a useful protection against any demand for excessive bail.

\section{Fair Hearing and Administrative Justice:}

As in the previous section on fair hearing under 1963 Constitution, this section also contains impressive list of rules in relation to criminal trials and procedures. However, I intend to concentrate on section 29(1) dealing with the determination of a person's civil rights and obligations. Though in some respect the section has greatly improved on section 22(1) of 1963 Constitution, it is not without its problems.

First, the initial difficulty of what amounts to a civil right ${ }^{54}$ or obligation is still there, and presumably the constitution still uses the words in contradiction from a criminal offence ${ }^{55}$. Secondly, the provision in sub-section 22(2) still stand albeit greatly modified in effect by the addition of two new items to the sub-section. According to 29(2) of the Draft, nothing in the provisions of subsection 29(1) shall invalidate any law by reason only that it confers on any authority powers to determine questions arising in the administration of a law that affect or may affect the civil rights and obligations of any person. This proviso is itself now subjected to two limitations. First, that such law provides for an opportunity for the person whose rights and obligations were affected to make representations to the administering authority before a decision affecting him could be taken. This is to be greatly welcomed and provided the courts do not take a narrow view of the meaning of civil rights and obligations, it will represent a major advance in this area of administrative justice.

Secondly, the law must not contain any provision that makes the determination of the administering authority final and conclusive. From the point of view of an

\footnotetext{
50 S. 27, Draft Constitution.

51 S. 19 (2) 1963 Constitution - Similarly the reference to existing law that may take away the right to life has been deleted. See s. 18 (3) 1963 Constitution \& compare s. 26 Draft Constitution. Also the tiking away of the right to life could either be in defence form, unlawful violence, or to effect a lawful arrest, the words emphasised being new additions.

52 S. 28, Draft Constitution.

5328 (3) b.

54 The issue question was avoided in the Marchats Bank Case, note 43 above.

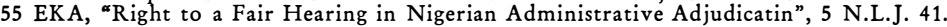


affected individual, item ii sub-section 29(2) may save him the trouble of having to challenge such clauses in Certiorari proceedings; but certainly, the use of such clauses would not have prevented him access to the courts. All they would have meant would be that the decision was final and conclusive at that stage, but no more. But from the angle of the Administrative Authority, there may be situations where it seems that certain finality to the proceedings at a certain level is desirable. It would seem that item (ii), subsection 29 (2) may curtail their freedom of action in that regard. So, perhaps it is time that the whole issue of administrative justice should be dealt with more comprehensively, may be by an Administrative Procedure Act.

\section{(b) Issues of Controversy}

Here I shall briefly touch on certain sections which, to my mind, have become the subject of some controversy.

\section{(i) Freedom of Expression:}

There is no quarrel. I believe with the section as it affects individuals generally; most people would agree that section 32 of the Draft, subject to the limitation imposed by section 38, adequately guarantees freedom of expression. Not only is every person entitled to freedom of expression, including his freedom to hold opinions and to receive and impart ideas and information, but is also free to own, establish and operate, any medium - not being a television or wireless broadcasting station - for the dissemination of such opinions and ideas. Where suggestions for reform are made, these are usually directed to the sedition laws of the country ${ }^{56}$. The issues of controversy are whether this section is equally sufficient for the protection of the Press and, secondly, whether there is any justification for the exclusive ownership of radio and television by the government. I must confess that on both issues I am in favour of the Draft proposals though in the case of television, my endorsement of the provision is rather qualified. As regards freedom of the Press, I fail to see how what more freedom could be given other than perhaps, the section should be worded in absolute terms like the American Constitution, "Parliament shall make no law abridging the freedom of the Press", and we have already indicated that such wording may be undesirable in the Nigerian context. Moreover, section 16 of Chapter II on the Fundamental Objectives states that "the Press, Radio, Television and other agencies of the mass-media shall at all times be free to uphold the fundamental objectives - and uphold the responsibility and accountability of the government to the people". So, it is my belief that the freedom given to the press under the constitution is adequate. What are perhaps called for are some restraints. There may be a need for a Press Council to set standards for Journalism in the country, and to receive complaints about the abuse of Press freedom. While I agree that the laws relating to sedition should be 
amended, I am of the firm belief that the defamation and libel laws are not enough for the protection of the privacy and reputation of citizens.

As regards Radio and Television, the matter, to me, seems rather different. To allow individuals to control radio and television is to allow a few rich people to control a most effective propaganda weapon. And they may not even be Nigerians or, if they are, they may merely be a front organisation for a multinational corporation. But I am not unaware of the danger of their abuse by the government, or the future President, as did de Gaulle in the 1960's, by the excessive projection of his personality through government controlled radio and television ${ }^{57}$.

"General de Gaulle was able to play havoc with his own Constitution because of his undisputed personal prestige as a leader who had raised France's stature in the world, and the complete governmental control of state-owned telecommunications which are the primary means of forming public opinion ${ }^{58}$."

Herein lies the dilemma. But I would suggest that we should try and see to it that these public corporations are as free from government interference as possible, perhaps by making them accountable to an all party committee of the national assembly.

\section{Freedom from discrimination}

Under section 35 of the Constitution, it would seem that it is still possible to discriminate between citizens in connection with employment to an office under a state, or as a member of the Armed Forces, the Police or a body corporate established directly by law in Nigeria. But in two respects the section improves greatly on the 1963 Constitution. No longer would any citizen be barred from acquiring any land or property anywhere in the federation simply because of his membership to a particular ethnic, religious or political group. Nor would any legislative or executive action be allowed to authorise the expenditure of public funds for the purpose of religious instruction in a manner that would deny equitable treatment to other religious groups.

However, in another respect, the section creates a controversy, at least for someone from ABU. You see, section 35(3) seeks to protect children born out of wedlock, by providing that they must not suffer in any way by virtue of that fact alone. Now, I do not claim to have any special knowledge of Islamic law, but my feeling is that this section, if pursued to its logical conclusions would, ultimately, and in a proper case, conflict with a Sharia rule of inheritance. The legal drafting committee was apparently aware of this, but their humanitarian ideals prevailed and the muslims' susceptibilities may be wounded. I must admit my feeling of unease about raising this issue, but I felt the point should be made.

\section{(c) Possible Future Problems}

Here I intend to speculate a little bit about the sort of problems that are likely to crop up in the interpretation of the bill of rights.

58 Loewenstein, K. Political Power and the Governmental Process 2nd ed., Chicago, 1965, p. 394. 


\section{(i) Fundamental Rights v. Directive Principles}

I have earlier indicated that the compromise solution of adopting social and economic rights not as fundamental rights, but as part of the general principles of state policy may create problems in the future. Let me now try to explain this point.

\section{(x) Right to property v. socialist ideals}

S. 36 of the Draft Constitution protects the right of every person to own or hold property, and that such property if at all taken compulsorily for a public purpose, he is entitled to a "prompt payment of adequate compensation".

So the section does not simply insist on the payment of compensation, but that the compensation paid must be adequate. Now, look at the Directive Principles. Take S. 10 (1)(a) for example: The state shall "control the nation d ecoromy in such a manner as to secure the maximum welfare . . . of every Nigerial. citizen". Can the government then on the basis of this nationalize all land in the country so as to provide for all the citizens "adequate means of livelihood" (s. 11[3][c]? What then is going to be the position? Is the government expected to pay adequate compensation to everyone whose land has been affected by such exercise?

In India, where the Constitutional position was similar to that of Nigeria Directive principles and fundamental rights - the issue resulted in many constitutional amendments and head-on collisions between the government and the judiciary. In the end, the fundamental rights provisions were subjected to the Directive principles of state policy, and any law giving effect to such directive principles could not be challenged on the basis that it conflicts with any fundamental right ${ }^{59}$.

\section{(c) S. 11 (2) and S. 35 (3)}

I have already dealt with s. 35(3) and expressed the view that it may possibly afford against a rule of Islamic Law. Yet section 11(2) clearly maintains that in promoting the social order of the society, no law brought out to effect this should invalidate a rule of Islamic Law. Is there a possible contradiction here?

\section{(ii) Emergency provisions:}

A lot would agree that the emergency provision contained in s. 70 (2) of the 1963 Constitution, allowed parliament a free hand, and that the courts did not have any powers to control parliament in any way. So now under s. 39(5) the courts will be competent to judge the factual situation for themselves.

Yet the criteria used would seem to involve the judiciary in delivering political questions.

59 See articles $31 \mathrm{~A}, 31 \mathrm{~B}$, and $31 \mathrm{C}$ of the Indian Constitution. For a scathing attack on all these - see: Palkhivala, N. A., Our Constitution Defaced and Defiled, Delhi, 1974. 
How are the courts to determine whether or not the federation is in imminent danger of invasion for example? My feeling is that this area too may prove equally problematic in future.

\section{Final Remarks}

I would like, finally, to make three passing remarks:

First: In the past, the provisions relating to legal representation were ineffective largely because most citizens could not afford to pay for a lawyer to defend them ${ }^{60}$ It is heartening, therefore to see that it is suggested in the Constitution that the National Assembly should in future provide for legal aid. And one hopes that the provisions of such legislation would be much wider in scope than the present Legal Aid Decree.

Secondly: We must remember that fundamental guarantees of freedom are often valueless if there does not exist the will and the determination to maintain them. Liberty, they say, lies at the hearts of men. And one is glad to note that the love of freedom is very much alive in the hearts of Nigerians and perhaps this, more than anything else, may prove a most effective protection against the erosion of their rights ${ }^{61}$.

And finally - I beg your forgiveness to make a last point - under Nigerian Law, there is, as yet, no right of appeal to alien against deportation. Could the fundamental rights provisions possibly be extended to cater for this?

60 Oretuyi, S. A., "The Nigerian Attempt to Secure Legal Representation by a Bill of Rights: Has it Achieved its Objective?" (1975) 17 Malaya Law Review p. 149.

61 Proehl op. cit. p. 1. 


\title{
Fundamental Rights and the Nigerian Draft Constitution
}

\author{
By A. S. Fadlalla
}

Under the 1963 Constitution, Nigeria had an impressive list of Fundamental Rights modelled on the European Convention of Human Rights. Those guarantees, with some modifications, became the basis for the New Draft. In the past, these guarantees were criticised for being "liberal" rights that make no reference to the social or economic rights of the individual; that they were merely "declaratory" of existing law and that they were so hedged with exceptions as to render them ineffective in practice. Moreover, the Judiciary was criticised for adopting a too cautious attitude in interpreting those guarantees. None of these criticisms, however, need derogate substantically from their effectiveness.

The New Draft shows many marked improvements. The drafting is more neat and for once the emphasis is first placed on the rights protected, followed by the recognised exceptions, many of which had been removed. However, it is still possible to limit most of the rights by a law which is "reasonably justifiable in a democratic society" an elusive phrase which has not been clearly defined by the courts. Needless to say that a lot would still depend on the attitude of the courts, and it is suggested that they might be helped in this task if the word "necessary" should be substituted for "reasonably justifiable" as something could be reasonably justifiable without being necessary.

The paper also points out certain issues of controversy pertaining to freedom of the Press and freedom from discrimination. And finally it draws attention to some other areas where possible problems might arise in future, notably, the likely conflict between the Bill of Rights and the list of Directive Principles e. g. by insisting on the entrenchment of the right to property and the payment of adequate compensation for any interference with it, the Bill may have made it difficult for any future government bent on securing the "maximum welfare" of every Nigerian citizen so to act.

\section{The United States and Latin America}

\section{By KNUd KRAKAU}

In the short run the Carter administration uses the by now familiar carrotand-stick tactics vis-à-vis Latin American governments: granting or with-holding foreign aid (military, economic), thereby rewarding or punishing the good or the bad governments, respectively - now in the interests of "human rights". In the past the good/bad guys were defined in terms of their attitudes towards fascism, "international communism", democracy, dictatorship, free elections, nationalization of foreign (American) property etc. But at the same time perspectives seem to change in a more fundamental way. For more than a century and a half US relations with Latin America have been troubled by the very "success" of the most hallowed US foreign policy taboo, the Monroe Doctrine. Thoug really no success at all or if, at least so for the wrong reasons, it later served as a convenient cloak for a hard-nosed hegemonial policy and misled the US until very recently into 